Abdullahi SM
Yakubu AM
Bugaje MA
Akuyam SM

DOI:http://dx.doi.org/10.4314/njp.v47i2.4

Accepted: 24th March 2020

Abdullahi SM ( $\boldsymbol{\nabla})$

Yakubu AM, Bugaje MA

Department of Paediatrics,

Akuyam SM

Department of Chemical Pathology Ahmadu Bello University Teaching Hospital Zaria, Kaduna State. Email:sakinaabdullahi2013@gmail.com

\title{
CC-BY Socio-economic variables of children with undernutrition and their controls in Ahmadu Bello University Teaching Hospital Zaria
}

\begin{abstract}
Background: Low socio-economic and educational levels of parents are important risk factors for under-nutrition in children. The distribution of health and diseases in childhood had been shown to be strongly influenced by the social characteristics like occupation and educational attainment. The aim of this study was to determine the socioeconomic status among children with Protein Energy Malnutrition and the Controls in Zaria using the modification of the method earlier used by Oyedeji.

Method: This study was a case control health- based descriptive study to determine the socioeconomic and demographic variables in undernourished children in Zaria.

Using systematic sampling method, a total of 132 children (cases and controls) between 6 and 59 months of age were selected for assessment of socioeconomic and demographic variables. Results: Nineteen $(28.8 \%)$ of the
\end{abstract}

study group belong to social class III as compared to $12(18.2 \%)$ for the controls. As for the educational levels of the parents, among the cases, $28(42.4 \%)$ had Islamic education, $25(37.9 \%)$ had secondary education, $10(15.1 \%), 2(3.0 \%)$ and $1(1.5 \%)$ had primary, tertiary and no formal education respectively. For the controls, 7 (10.6\%) had Islamic education, 34 (51.5\%) had secondary education, 13 $(19.7 \%)$ and $12(18.1 \%)$ had primary and tertiary education respectively. There was none with no formal education, The statistical analysis showed significant difference $(\mathrm{P}=0.0009)$ between cases and controls for maternal educational levels only among the demographic data.

Conclusion: This study has been able to establish low socio- economic factors among undernourished children studied.

Keywords: Under-nutrition, socioeconomic factors, educational levels, children

\section{Introduction}

Malnutrition (Under-nutrition) is defined as an imbalance between nutrient requirements and intake resulting in cumulative deficits of energy, protein or micronutrients that may negatively affect growth, development and other relevant outcomes. ${ }^{1,2}$ Stunting, underweight and wasting are indices of malnutrition, ${ }^{2,3,4}$ These are defined respectively as anthropometric measurements that fall below minus two standard deviation $(<-2 \mathrm{SD})$ of normal height/length-for-age, weight-for-age, weight-for-height/ length of the median World Health Organization (WHO) child growth standards. ${ }^{3,45}$ Severe acute malnutrition (SAM) is defined by a weight-for-height/length below $3 z$-scores of the median WHO growth standard, (<-3SD) by visible severe wasting or by the presence of nutritional oedema. ${ }^{4,6}$ Severe acute malnutrition remains a major cause of mortality in children under five years of age. ${ }^{4}$ It has been estimated that more than 20 million children of the world mostly developing nations suffer from severe malnutrition and 150 million children are underweight. ${ }^{3,4.7}$ Globally, in 2012, 51 million children under five years were wasted, 17 million had severe wasting and twenty-eight per cent of all severely wasted children are living in Africa. ${ }^{6.8}$ In Nigeria, $24 \%$ of children under five years of age are underweight (9\% severely), 36\% are stunted (19\% severely) and 10\% are wasted (3\% severely). ${ }^{7,8}$ Malnutrition rates in the North Western and North Eastern regions of Nigeria are higher than in the Southern parts of the country. The National Demographic Health Survey (NDHS) reports of 2003, 2008 and 2013 show declining prevalence of stunting in children under-five years of age at $42 \%, 41 \%$ and $37 \%$ respectively. Prevalence of wasting however was rising at $11 \%, 14 \%$ and $18 \%$ respectively. Underweight was $24 \%, 23 \%$ and $29 \%$ in those respective years. The trend shown in the statistics on malnutrition depict significant malnutrition in the regions mentioned. The figures are 
compelling and create a need for further research on associated factors. Physical findings generally help in the diagnosis of advanced malnutrition but is not frequently positive in children in mild and moderate degree of malnutrition. ${ }^{8}$ Early diagnosis of these cases is very useful as they are amenable to early rehabilitation and have better prognosis.

The distribution of health and diseases in childhood had been shown to be strongly influenced by the social characteristics like occupation and educational attainment. ${ }^{9}$ The incidence and severity of common childhood infections and nutritional disorders as well as the utilization of health services and intervention programmes had been shown to be influenced by these social factors. ${ }^{10}$ Thus appropriate social classification of children is desired in order to focus attention at social groups which may put children at risk of poor health conditions.

Thirty-five years ago, Oyedeji ${ }^{11}$ proposed a method of socio-economic classification of children derived from the occupation and educational qualifications of both parents. This classification of parents was based on the prevailing economic realities in the country characterised by the riches of the oil boom. Thereafter, the economic fortunes of the country began to dwindle and economic reform programmes like Structural adjustment programme were introduced. There are sociological and economical evidences that such economic reform programmes led to increasing poverty in the country. ${ }^{11,12}$

Over the years, the national economy had worsened with increasing rates of unemployment, inflation and poor purchasing powers. ${ }^{12}$ With high unemployment rate, high educational attainment may not necessarily guarantee a good job and may not statutorily translate to high purchasing owners. ${ }^{12}$ Similarly, the salaries and wages of employees both in the public and private sectors of the economy had been repeatedly upwardly reviewed within the last two decades without commensurate increments in the wages of self-employed workers. ${ }^{12}$ Therefore it is imperative to review and modify the subsisting method of socio-economic classification of children to reflect the current financial strength of the parents. Thus, the objective of this study is to determine the socio-economic status of undernourished and wellnourished children in Zaria using a modification of the method earlier used by Oyedeji. ${ }^{11}$

\section{Materials and methods}

This was a case-control hospital-based descriptive study conducted over a period of 10 months between June, 2010 and March, 2011.

The study was carried out at the Institute of Child Health (ICH) Banzazzau, Zaria. The Institute of Child Health serves the community/ children mainly from Zaria and its environs and is the Primary Health Care outlet of Ahmadu Bello University Teaching Hospital (ABUTH), Zaria. The ICH offers out-patient service and receives an average of 200 patients in a day. ICH is located in Banzazzau area within the walled city of Zaria. Systematic sampling method was adopted to select 132 children between 6 and 59 months of age in Zaria. The study population consisted of consecutive malnourished children between the age of 6-59 months who presented to ICH. WHO Z-score classification was used in the classification of malnutrition in this study into mild, moderate and severe malnutrition using weight, height/length, MUAC and presence or absence of oedema. Age matched well malnourished children who presented to the ICH with clinical features of malaria, ARIs, acute diarrhoeal diseases among others were enrolled as controls. Informed consent was duly obtained from each child's parents or care givers before recruitment in the study. The sample size was determined using the following formular: ${ }^{13}$

$$
S=\frac{\left[Z 1-\frac{\alpha}{2} \sqrt{2 P_{2}\left(1-P_{2}\right)}+Z_{1}-\beta \sqrt{P_{1}\left(1-P_{1}\right)+P_{2}\left(1-P_{2}\right)}\right]^{2}}{\left(P_{1}-P_{2}\right)}
$$

The prevalence of under-nutrition used was $41.6 \%$. Relevant data using a proforma which included patient's name, age, sex, parental occupation and educational status, dietary history with particular emphasis on frequency of ingestion of protein - rich foods were collected from all children enrolled for the study.

The method of classification employed in this study was a modification of the method earlier used by Oyedeji. ${ }^{11}$ The modification was based on the use of parental income to assign to socio-economic scores. The socioeconomic scores ( 1 to 5 ) were given to each child based on the scores awarded to the occupation and educational qualification of each parent. The scores given to each occupation and educational qualification were also derived from the average monthly incomes. The mean incomes for each educational qualification and occupation were determined. The incomes of the fathers and mothers were described in percentiles $\left(10^{\text {th }}, 25^{\text {th }}, 50^{\text {th }}, 75^{\text {th }}\right.$ and $\left.90^{\text {th }}\right)$, the equivalents of the mean income for each educational status and occupation were derived from the set percentile incomes, therefore, scores of 5, 4, 3, 2 and 1 were assigned to incomes equivalent to the $10^{\text {th }}, 25^{\text {th }}$, $50^{\text {th }}, 75^{\text {th }}$ and $90^{\text {th }}$ percentiles of the incomes for the fathers and mothers. Therefore, a score was awarded for the education and occupation of each parent and the mean of these four scores to the nearest whole number was the socio-economic status (I, II, III, IV and V respectively) assigned to the child. For example, a father who was a HND holder and a banker would score 2 for his education and 1 for his occupation. If his wife was a bachelor degree holder and a senior government employee, she would score 2 for her education and another 2 for her occupation. The sum of the four scores in this case would be 7 and the average would be 1.75 and 2 to the nearest whole number. Thus the socio-economic class of the child of these hypothetical parents would be II.

History of preceding illnesses within two weeks such as measles, diarrhoeal diseases and acute respiratory infec- 
tions were recorded. Physical examination looking for skin changes, hair changes and oedema was carried out and also the anthropometric measurements. ${ }^{3,4,5}$

Approval for the study was obtained from ethical committee of Ahmadu Bello University Teaching hospital Zaria.

Obtained data was compiled and analysed using statistical package for social sciences (SPSS) version 15.4. Comparison of mean values was done using Student $\mathrm{t}$-test and level of significance was set at $\mathrm{p}<0.05$.

\section{Result}

General characteristics of studied cases and controls

A total of 66 each for the cases and age-matched controls were sampled for the study. The sociodemographic variables for both groups are as shown in table 1 . Twenty six (39.4\%) were males and $40(60.6 \%)$ were females with a male: female ratio of 1:1.5 among cases while for the controls, $30(45.5 \%)$ were males and $36(54.2 \%)$ were females with a male: female ratio of $1: 1.2$.

\begin{tabular}{|c|c|c|c|c|}
\hline Variables & $\begin{array}{l}\text { Cases } \\
\mathrm{n}(\%) \\
\end{array}$ & $\begin{array}{l}\text { Control } \\
\mathrm{n}(\%)\end{array}$ & $\mathrm{X} 2$ & $\mathrm{P}$ value \\
\hline \multicolumn{5}{|l|}{ Gender } \\
\hline Males & $26(39.4)$ & $30(45.5)$ & 0.49 & 0.48 \\
\hline Females & $40(60.6)$ & $36(54.2)$ & & \\
\hline \multicolumn{5}{|l|}{ Tribe } \\
\hline Hausa & $50(75.6)$ & $52(78.8)$ & & $0.82 *$ \\
\hline Fulani & $12(18.2)$ & $10(15.2)$ & & \\
\hline Yoruba & $2(3.0)$ & $3(4.5)$ & & \\
\hline Others & $2(3.0)$ & $1(1.5)$ & & \\
\hline \multicolumn{5}{|l|}{ Age } \\
\hline $6-12$ & $18(27.3)$ & $18(27.3)$ & & $1.000 *$ \\
\hline $13-24$ & $38(57.6)$ & $38(57.6)$ & & \\
\hline $25-36$ & $6(9.1)$ & $6(9.1)$ & & \\
\hline $37-48$ & $2(4.5)$ & $2(4.5)$ & & \\
\hline $49-59$ & $2(4.5)$ & $2(4.5)$ & & \\
\hline \multicolumn{5}{|l|}{ Social class } \\
\hline I & $1(1.5)$ & $3(4.5)$ & & $0.09 *$ \\
\hline II & $8(12.1)$ & $19(28.7)$ & & \\
\hline III & $19(28.8)$ & $12(18.2)$ & & \\
\hline VI & $28(42.4)$ & $22(33.3)$ & & \\
\hline $\mathrm{V}$ & $10(15.1)$ & $10(15.2)$ & & \\
\hline \multicolumn{5}{|c|}{ Educational levels } \\
\hline None & $1(1.5)$ & $0(0.0)$ & & \\
\hline Islamic & $28(42.4)$ & $7(10.6)$ & 18.47 & 0.0009 \\
\hline Primary & $10(15.1)$ & 13 (19.7) & & \\
\hline Secondary & $25(37.9)$ & $34(51.5)$ & & \\
\hline Tertiary & $2(3.0)$ & $12(18.1)$ & & \\
\hline
\end{tabular}

Others $=$ Nupe, Igala, Southern Kaduna. $*=$ fishers exact

Table 2 shows occupations of the parents and their mean monthly incomes for cases and controls respectively. Tables 3 shows the various educational status of the parents and their mean monthly incomes for both cases and controls respectively. The fathers were mainly sen- ior government workers $(33.3 \%$ and $30.3 \%)$ for both cases and controls respectively while the mothers were mainly unemployed $(28.8 \%)$ of cases and senior government workers $(18.8 \%)$ for the controls.

The leading educational qualification for both groups of parents were secondary (34\% and $51.5 \%$ ) for fathers in both cases and controls while among the mothers were Islamic in $22.7 \%$ of cases and primary in $48.5 \%$ among the controls.

The monthly income of all the parents ranged from zero to 500,000 thousand naira $(\mathrm{NGN})$ the mean $( \pm \mathrm{SD})$ of $20.919 \mathrm{NGN}( \pm 27,311.5 \mathrm{NGN})$. The $10^{\text {th }}, 25^{\text {th }}, 50^{\text {th }}, 75^{\text {th }}$ and $90^{\text {th }}$ percentiles were $0,6,000,13,000,30,000$, 50,000 NGN respectively.

Table 4 shows the socioeconomic scores assigned to educational qualifications and occupation based on the equivalents of their mean incomes in the percentile incomes described below. The least scores were assigned to the most highly educated and the best employed.

Table 5 shows the classification of the children studied into socioeconomic groups using the socioeconomic scores shown in table 4 . The subjects were concentrated in socioeconomic classes III and IV.

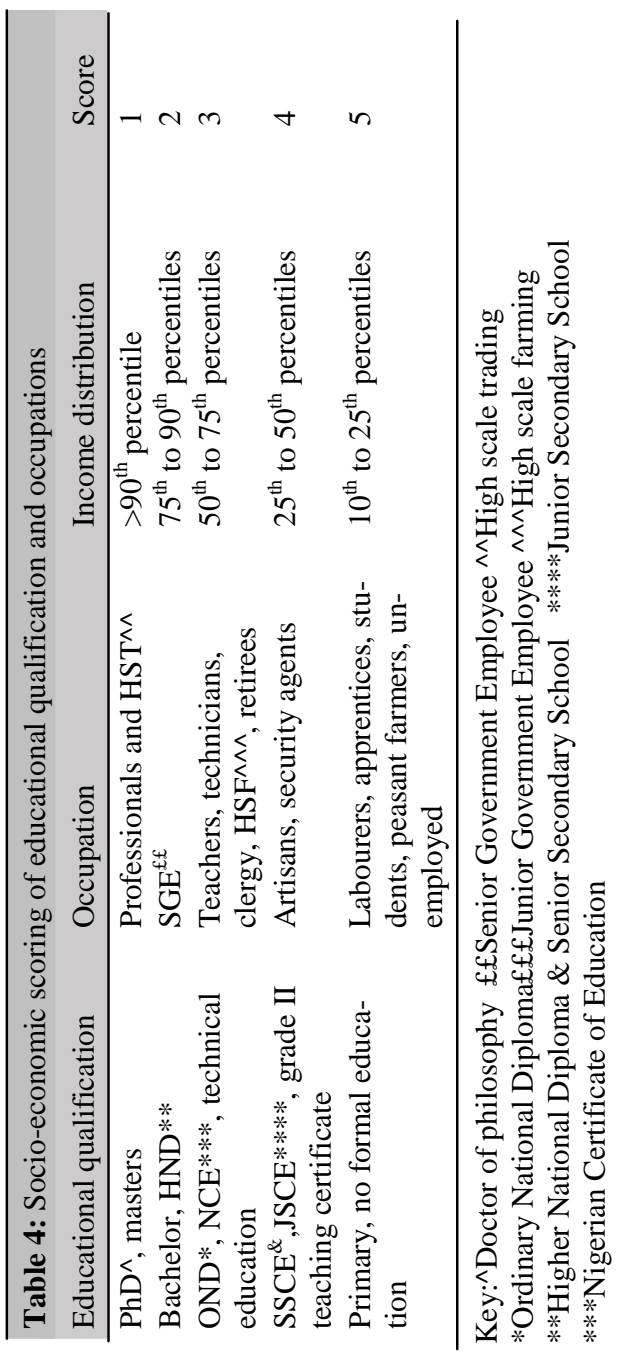




\begin{tabular}{|c|c|c|c|c|c|c|c|c|}
\hline \multirow[t]{2}{*}{ Occupation } & \multicolumn{3}{|c|}{ Cases } & \multicolumn{3}{|c|}{ Controls } & \multirow[b]{2}{*}{$\begin{array}{l}\text { Mothers } \\
\mathrm{n}(\%)\end{array}$} & \multirow[b]{2}{*}{ NGN } \\
\hline & $\begin{array}{l}\text { Fathers } \\
\mathrm{n}(\%)\end{array}$ & NGN & $\begin{array}{l}\text { Mothers } \\
\mathrm{n}(\%)\end{array}$ & NGN & $\begin{array}{l}\text { Fathers } \\
\mathrm{n}(\%)\end{array}$ & NGN & & \\
\hline Professionals(doctors, lecturers) & $1(1.5)$ & $68,784)$ & $0(0.0)$ & 0 & $3(4.5)$ & 68,784 & $4(6.1)$ & 58,368 \\
\hline $\begin{array}{l}\text { Artisan(tailors, hair dressers, vulcaniz- } \\
\text { ers, bricklayers) }\end{array}$ & $5(7.8)$ & 11,081 & $6(9.1)$ & 8,215 & $4(6.1)$ & 11,081 & $3(4.5)$ & 8,215 \\
\hline $\begin{array}{l}\text { High scale farming(cash crops, live } \\
\text { stocks) }\end{array}$ & $4(6.1)$ & 27,345 & $5(7.6)$ & 28,967 & $5(7.6)$ & 27,345 & $4(6.1)$ & 28,967 \\
\hline Low scale farming(peasant) & $6(9.1)$ & 3,450 & $3(4.5)$ & 2,103 & $5(7.6)$ & 3,450 & $3(4.5)$ & 2,103 \\
\hline $\begin{array}{l}\text { Teachers(primary, secondary, posts } \\
\text { secondary) }\end{array}$ & $4(6.1)$ & 23,729 & $12(18.2)$ & 19,906 & $4(6.1)$ & 23,729 & $12(18.2)$ & 19,906 \\
\hline Junior government workers & $12(18.2)$ & 18,552 & $10(15.2)$ & 15,062 & 13(19.7) & 18,552 & $10(15.2)$ & 15,062 \\
\hline Senior government workers & $22(33.3)$ & 40,637 & $3(3.0)$ & 35,487 & $22(33.3)$ & 40,367 & $2(3.0)$ & 35,487 \\
\hline $\begin{array}{l}\text { Petty trading(grocery sellers and street } \\
\text { hawking) }\end{array}$ & $3(4.5)$ & 6,819 & $6(10.6)$ & 0 & $3(4.5)$ & 6,819 & $9(13.6)$ & 0 \\
\hline Retirees & $7(10.4)$ & 0 & $2(3.0)$ & 0 & $5(7.6)$ & 0 & 0 & 0 \\
\hline Unemployed & $2(3.0)$ & 29,675 & $19(28.8)$ & 0 & $2(8.0)$ & 29,675 & $19(28.8)$ & 0 \\
\hline Total & $66(100)$ & & $66(100)$ & & $66(100)$ & & $66(100)$ & \\
\hline
\end{tabular}

Key: mean income in Nigerian naira (NGN135 is equivalent to $1 \$$ ) when study was done

\begin{tabular}{|c|c|c|c|c|c|c|c|c|}
\hline \multirow[t]{2}{*}{ Highest educational qualification } & \multicolumn{3}{|c|}{ Cases } & \multicolumn{5}{|c|}{ Controls } \\
\hline & $\begin{array}{l}\text { Father } \\
\mathrm{n}(\%)\end{array}$ & $\mathrm{NGN}^{\#}$ & $\begin{array}{l}\text { Mother } \\
\mathrm{n}(\%)\end{array}$ & $\mathrm{NGN}^{\#}$ & $\begin{array}{l}\text { Father } \\
\mathrm{n}(\%)\end{array}$ & $\mathrm{NGN}^{\#}$ & $\begin{array}{l}\text { Mother } \\
\mathrm{n}(\%)\end{array}$ & $\mathrm{NGN}^{\#}$ \\
\hline $\mathrm{PHD}^{\wedge}$ & $0(0.0)$ & & & & $1(1.5)$ & 68,375 & $0(0.0)$ & \\
\hline Masters & $0(0.0)$ & & & & $2(3.0)$ & 61,133 & $0(0.0)$ & \\
\hline Bachelors & $5(7.6)$ & 42,445 & $5(7.6)$ & 32,604 & $4(6.1)$ & 42,445 & $4(6.1)$ & 32,604 \\
\hline HND* & $2(3.0)$ & 34,363 & $2(3.0)$ & 31,315 & $1(1.5)$ & 34,363 & $3(4.5)$ & 31,315 \\
\hline OND** & $1(1.5)$ & 26,947 & $2(3.0)$ & 13,606 & $1(1.5)$ & 26,947 & $2(3.0)$ & 13,606 \\
\hline $\mathrm{NCE}^{* * *}$ & $3(4.5)$ & 24,450 & $2(3.0)$ & 14,631 & $3(4.5)$ & 24,450 & $4(6.1)$ & 14,631 \\
\hline Secondary school & $34(51.5)$ & 11,550 & $32(48.6)$ & 7,500 & $34(51.5)$ & 11,550 & $32(48.5)$ & 7,500 \\
\hline Primary school & 13(19.7) & 11,833 & $15(22.7)$ & 4,500 & $13(19.7)$ & 11,833 & $15(22.8)$ & 4,500 \\
\hline Islamic & $7(10.7)$ & 4,433 & $7(10.6)$ & 5,000 & $7(10.7)$ & 4,433 & $6(9.0)$ & 5,000 \\
\hline None & $1(1.5)$ & & $1(1.5)$ & & $0(0.0)$ & & & \\
\hline Total & $66(100)$ & & $66(100)$ & & & & & \\
\hline
\end{tabular}

Key: ${ }^{\#}$ mean income in Nigerian naira(NGN135 is equivalent to $\$ 1$

$\wedge$ Doctor of philosophy $\quad * *$ Ordinary National Diploma

*Higher National Diploma $\quad * * *$ Nigerian Certificate of Education

\begin{tabular}{llll}
\hline \multicolumn{4}{l}{ Table 5: Socio-economic classification of 132 children } \\
Variables & Study group n(\%) & $\begin{array}{l}\text { Control group } \\
\mathrm{n}(\%)\end{array}$ & P-value \\
\hline Social class & & & \\
I & $1(1.5)$ & $3(4.5)$ & 0.06 \\
II & $8(12.1)$ & $19(28.7)$ & \\
III & $19(28.8)$ & $12(18.2)$ & \\
IV & $28(42.4))$ & $22(33.3))$ & \\
V & $10(15.1)$ & $10(15.2)$ & \\
Total & $66(100)$ & $66(100)$ & \\
\hline
\end{tabular}

\section{Discussion}

The present study shows that half of the studied children utilizing the institute of child health Zaria, Nigeria belonged to the lower socioeconomic classes. It is not clear why children in the upper socioeconomic classes were few in the present study despite the semi-urban location of the study centre, but it is postulated that the parents in upper socioeconomic classes may choose to patronise privately owned facilities.

Although the fathers are generally more educated than the mothers in the cases and controls, the proportions of parents without formal education were remarkably lower than what Ogunlesi ${ }^{14}$ found in 2008 that used the same social classification. While $89.4 \%$ of the fathers and of $87.7 \%$ of the mothers in Ogun state had at least secondary education, $51.5 \%$ of the fathers and $48.5 \%$ of mothers had similar educational qualification in the present study. However, there are many similarities in the pattern of occupation of the parents observed in this study and that of Ogunlesi. ${ }^{14}$ In the present study, 3\% and $28.8 \%$ of the fathers and mothers were unemployed among the cases while $8 \%$ of the fathers and $28.8 \%$ of mothers were unemployed among the controls. This was comparable to $1 \%$ and $12.6 \%$ of fathers and mothers respectively as previously reported by Ogunlesi. ${ }^{14}$ Similarly, $6.1 \%$ and $18.2 \%$ of the fathers and mothers respectively in the present study among both cases and controls were teachers compared to $8.4 \%$ and $16.1 \%$ respectively as reported by Ogunlesi. ${ }^{14}$ The proportion of mothers who were petty traders in the present studywas $13.6 \%$ compared with $21.2 \%$ previously re- 
ported by Ogunlesi. $^{14}$

The actual incomes of the parents were used to assign socio-economic scores to their education and occupation in the present study. As a result of this modification, the socio-economic classes to which most of educational qualification and occupations belonged to class III. Senior government employees and junior employees belonged to classes II and III respectively, while labourers and messengers belonged to class $\mathrm{V}$ in the present study. This study was comparable to the previously reported study by Ogunlesi whose, socio-economic classes to which most educational qualifications and occupations belonged. For instance, teachers belonged to socioeconomic class III. Similarly, senior government employees and junior government employees also belonged to II and III respectively. ${ }^{14}$ On the educational qualifications, parents with secondary and primary education belonged to classes IV and V respectively in the present study.

The socio-economic status of children is better related to the financial strength of the parents. Therefore, the methods of socio-economic classification need to be periodically reviewed with respect to the subsisting economic situation of the country.

\section{Conclusion}

Most of the parents in the present study had average educational attainment but most of their children be- longed to lower socio-economic classes.

This disparity might have arisen from poor employment and poor finances. Therefore, appropriate classification of the social status of children most necessarily take into consideration the prevailing economic status of the parents, The method of socio-economic classification derived from this study, is therefore recommended in view of the prevailing economic situation of most families in the country.

\section{Acknowledgements}

I acknowledge with thanks, the staff of paediatrics and chemical pathology departments and institute of child health ABUTH Zaria.

Author's contributions
Abdullahi SM: Planning, literature search, data collec-
tion, analysis and writing of manuscript
Yakubu AM: Revised the manuscript and supervised the
conduct of the study
Akuyam SM: Review of drafts of manuscript and super-
vision.
Bugaje MA: Review drafts of manuscript and supervi-
sion.
Conflict of interest: None
Funding: None

\section{Author's contribution} tion, analysis and writing of manuscript

Yakubu AM: Revised the manuscript and supervised the conduct of the study

Akuyam SM: Review of drafts of manuscript and supervision.

Conflict of intere
Funding: None

\section{References}

1. Mehta NM, Corkins MR, Lyman B. Defining paediatric malnutrition: a paradigm shift toward aetiology related definitions. J Parental Enteral Nutr 2013;37: 460-81.

2. De Onis M, Blossner M. The World Health Organization global database on child growth and malnutrition: methodology and applications. Int J Epoidemiol 2003;32(4):518-26.

3 . Indepth network. Indepth resource kit for demographic systems: Anthropometric indicators. Available from: http// www.indepth network.org/ Resource Kit/INDEPYH DSS Resource Kit/Anthropometricstatus-indicators.htm. Accessed on $27^{\text {th }}$ October 2015.

4. Abidoye RO. A study of prevalence of protein energy malnutrition among $0-5$ years in rural Benue State, Nigeria. Nutrition Health 2000;13:235-47.
5. WHO. Child growth standards and the identification of severe acute malnutrition in infants and children: WHO Library. 2009.1-12.

6. UNICEF. The state of the World s Children 2013: Children with disabilities .2013.

7. National Bureau of Statistics. Multiple indicators Cluster Survey. 2011.

8. National Population Commission. National Demographic Health Survey. 2013. Available from:http:www.population.gov. ng. Accessed on $12^{\text {th }}$ April 2014.

9. Spencer N. Social, economic and political determinants of child health. Paediatrics 2003; 112:704-6.

10. Oyedeji GA, Oyedeji OA, Ajibola AJ. The association between social disadvantage and morbidity in hospitalized children. Niger J Paediatr 2002;29:5-10.
11. Oyedeji GA. Socio-economic and cultural background of hospitalised children in IIesha. Niger J Paediatr 1985;12:111 $-7$.

12. Nwajiuba CU, Nwoke BEB and Nwajiuba CA. Structural adjustment programme and public health issues in relation to migration: Nigeria. Development 2007; 50: 101-5.

13. Lemeshow S, Hosmer DW, Klar J. Sample size for case control studies: In Adequacy of sample size in health studies, New York. John Wiley and Sons (on behalf of WHO) 1990;16-20.

14. Ogunlesi TA, Dedeke IOF, Kuponiyi OT. Socioeconomic classification of children attending specialist paediatric centres in Ogun state, Nigeria. Niger Med Pract 2008;54(1):21-5. 